\title{
Inability of Galactose to Mobilize Insulin in Galactokinase-Deficient Individuals *
}

\author{
R. GTtzelmann and R. ILLig
}

Laboratory for Metabolic Research and Protein Hormone Laboratory, University Pediatric Department, Kinderspital, 8032 Zürich, Switzerland

Received: May 20, 1968

Summary. Oral galactose loading in two galactokinasedeficient adults produced the expected high and prolonged rise of galactose in peripheral blood, but no rise of circulating immunoreactive insulin.

Absence de stimulation insulinique par le galactose chez des individus déficients en galactokinase

Résumé. Chez deux adultes souffrant d'une déficience en galactokinase la charge orale de galactose a été suivie d'une hypergalactosémie prolongée sans aucune élevation de l'insuline immunoréactive plasmatique.
Das Fehlen von Insulinstimulation durch Galactose bei Patienten mit Galactokinase-Mangel

Zusammenfassung. Orale Belastung mit Galactose führte bei zwei Erwachsenen mit Galactokinasemangel zu. einer prolongierten Hypergalactosämie, aber nicht zu einem Anstieg des immunoreaktiven Insulins im Plasma.

Key-words: Insulin, galactose, galactokinase deficiency.

\section{Introduction}

Hypoglucosaemia after milk intake is a frequently reported finding in galactosaemia due to hereditary galactose-1-phosphate uridyltransferase deficiency [11], and can be prompted in such patients by oral galactose loading tests [4]. The phenomenon was originally ascribed to hyperinsulinism; however, in at least one galactosaemic patient, plasma insulin dropped after an oral galactose load [17].

Recently, a new genetic disorder of galactose metabolism, galactokinase deficiency, has been discovered [5]. Patients with this condition [6] are unable to phosphorylate galactose, and therefore do not metabolize it normally to glucose. Ingestion of lactose from millk and of galactose causes a prolonged rise of blood galactose and the appearance of galactose and galactitol together with some glucose in the urine; but - in contrast to the normal or the galactosaemic patient no changes of blood glucose. This abnormal metabolic situation was considered suitable for the reinvestigation of the question whether galactose evoked plasma insulin response. We should like to report the results of oral galactose and glucose loading tests in two galactokinase-deficient individuals ${ }^{1}$.

\section{Methods}

The two adult patients were described earlier (Cases 1 and 2, Ref. 6). Both patients had a history of nuclear cataracts in early childhood, virtually no galactokinase activity in red cells and whole blood, and excreted vary-

* Aided by: Julius Klaus-Stiftung Zürich; Schweizerischer Nationalfonds zur Förderung der wissenschaftlichen Forschung (Grant 3990).

\footnotetext{
${ }^{1}$ A preliminary report was given [7].
}

ing amounts of galactose and galactitol and some glucose in urine. At the time of the tests, H.K. was 45 years old, and his oldest sister M.F.-K. was 66. Tests were performed after an overnight fast, the patients being at rest. In H.K. and in a normal adult, $10 \%$ solutions in water of d-galactose or d-glucose were given by mouth on separate days; in M.F.-K. the oral galactose tolerance test was immediately followed by an oral glucose tolerance test, combined with a meal. In both patients, normal fasting blood glucose levels coincided with loss of galactose, galactitol and of small amounts of glucose in urine voided immediately before the test.

Venous blood was taken from the antecubital vein. Plasma insulin was determined by the radioimmunoassay according to the method of YALOW and Berson [19], glucose in blood by the glucose oxidase procedure (test combination Boehringer, Mannheim, Germany), galactose in blood with galactose oxidase (Miles Chemical Co., Elkhart, Indiana) according to RoTH, et al. [16].

\section{Results}

Ingestion of $30 \mathrm{~g}$ of galactose in patient H.K. caused the expected high and prolonged rise of blood galactose, no change of blood glucose or of plasma insulin (Fig. 1 a). The same dose of galactose administered to the normal subject caused only mild galactosaemia of short duration (Fig. $1 \mathrm{~b}$ ). When $50 \mathrm{~g}$ of glucose were given to the same patient, delayed and excessive hyperinsulinism was observed together with prolonged and exaggerated hyperglucosaemia, whereas blood galactose dropped slightly (Fig. 2a). The same test performed on the normal adult led to normal response of blood glucose and plasma insulin (Fig 2b)

When patient M.F.-K. was given $50 \mathrm{~g}$ of galactose, 
Patient H.K.

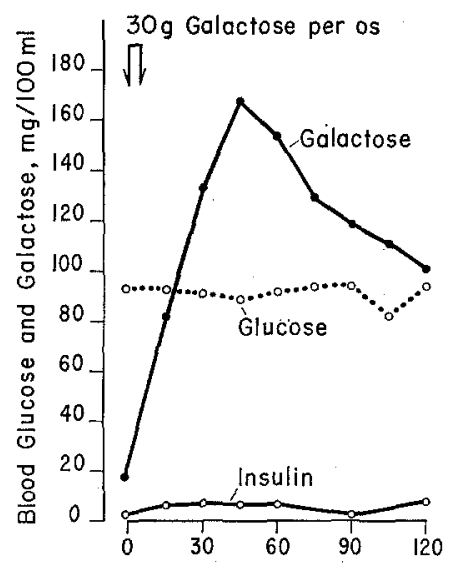

(a)

Patient H.K.

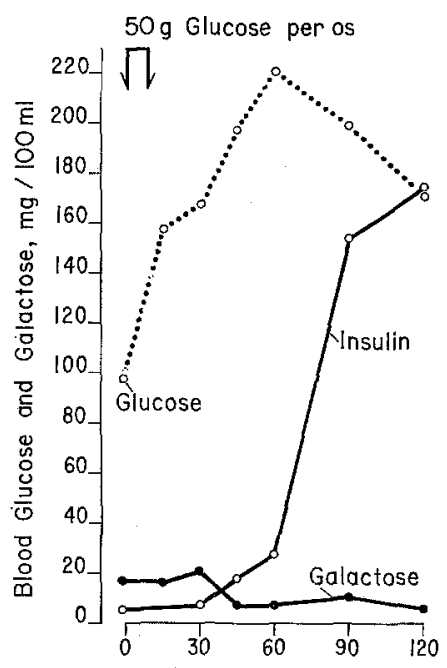

(a)

\section{Normal Subject}

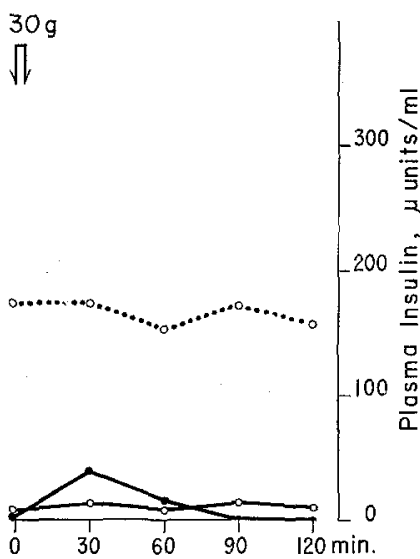

(b)

Normal Subject

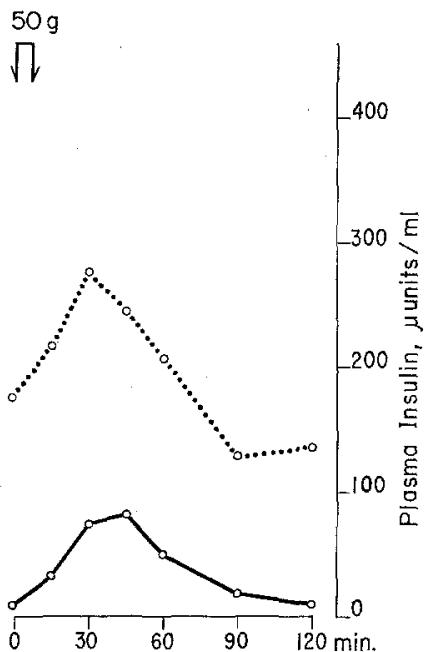

(b)

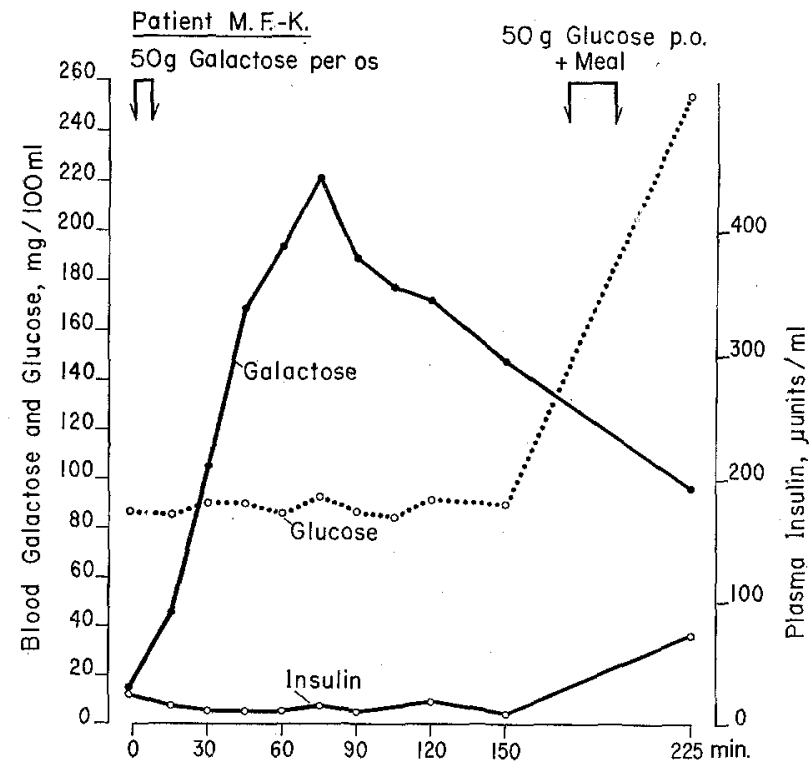

Fig. 1. Blood glucose and galactose and plasma insulin after oral administration of $30 \mathrm{~g}$ of galactose $(10 \%)$ to patient H.K. (a) and to a normal subject (b)

Fig. 2. Blood glucose and galactose and plasma insulin after oral administration of $50 \mathrm{~g}$ of glucose to patient H.K. (a) and to a normal subject (b)

Fig. 3. Blood glucose and galactose and plasma insulin after oral administration of $50 \mathrm{~g}$ of galactose, and subsequent administration of $50 \mathrm{~g}$ of glucose together with some solid food to patient M.F.-K. 
no plasma insulin response was observed during more than two hours of marked hypergalactosaemia (Fig. 3); ingestion of $50 \mathrm{~g}$ of glucose together with some solid. food evoked excessive hyperglucosaemia and a moderate but significant rise of plasma insulin, while blood galactose continued to drop.

\section{Comment}

In both patients, insulin release was evoked by glucose but not by galactose taken by mouth. This finding is in accordance with the one reported by Samous and Domandy [17], and also with a recent report by Hug and ScuUberT [10] who investigated serum insulin responses after intravenous administration of galactose to glycogenosis type I patients with inability to convert galactose to glucose. The demonstrated inability of galactose to evoke insulin release thus adds additional weight to the view of DuBoIs, et al. [2] that in galactosaemia, hypoglucosaemia after galactose load was due to a reduced rate of hepatic glucose release. This conclusion was derived from an elegant study in which it was shown that injection or ingestion of galactose caused a slowdown of glucose assimilation, and that the dilution rate of radioglucose in the blood of such patients dropped after administration of galactose while glucose continued to fall.

In most studies in vitro of isolated animal pancreas, galactose failed to stimulate insulin secretion $[9,1,3$, $18,14]$. However, in some experiments in vivo on dogs, injection of galactose into the pancreatic artery was followed by a drop of systemic blood glucose [15]. In a series of experiments which led to the proposal of an extrapancreatic carbohydrate-sensitive regulator of insulin secretion, GoETz et al. [8] observed a moderate increase in pancreatic insulin output after infusion of galactose into the portal vein (but no increase when galactose was injected into the pancreatic artery) even when blood glucose did not rise. The interpretation of the apparently conflicting experimental evidence is further complicated by the recent finding of LAMBERT et al., who report [12] a significant insulin release induced by galactose, from pancreatic explants of foetal rats in the presence of caffeine [13].

From the clinical studies presented here it would appear that high blood galactose did not stimulate insulin release at all; but it cannot of course be decided whether a stimulation of the pancreas itself, or of a possible extrapancreatic receptor, actually occurred but simply did not manifest itself in the peripheral blood.

It should be pointed out that the existence of a latent diabetes mellitus in patient H.K. was not anticipated. In the absence of confirming observations in other patients, it cannot be said whether this metabolic anomaly is a characteristic manifestation of galactokinase deficiency of long standing.

\section{References}

1. Coore, H. G., and P.J. RANDLE: Regulation of insulin secretion studied with pieces of rabbit pancreas incubated in vitro. Biochem. J. 93, 66-78 (1964).

2. Dobots, R., H. Loeb et H.A. Ooms: Etude du métabolisme glucidique dans la galactosémie et la fructosémie. Rev. franç. Ét. clin. biol. 7, 509-514, (1962).

3. Frerichs, H., U. Reich, u. W. CreutzFelot: Insulinsekretion in vitro. I. Hemmung der glucoseinduzierten Insulinabgabe durch Insulin. Klin. Wschr. 43, $136-140(1965)$.

4. Gentil, C., A.-M. Valette, A. Leimonnier, J. Colin, M. Odievre, R. Leluc, Thuong, C. Trdeu et D. At_A GILLE: Etude du métabolisme glucidique au cours de la galactosémie congénitale. Arch. franç. Pédiat. 23, 509-532 (1966).

5. Gitzelivann, R.: Deficiency of erythrocyte galactokinase in a patient with galactose diabetes. Lancet 1965 II, $670-671$.

6. - Hereditary galactokinase deficiency, a newly recognized cause of juvenile cataracts. Ped. Res. 1, $14-23(1967)$.

7. - Galactokinase deficiency. In: Galactosemia, Hsıa, D. Y.-Y., ed. Springfield: Charles Thomas 1968, in press.

8. Goetz, F.C., J.W. Maney, and B.Z. Grewnererg: The regulation of insulin secretion: Effects of the infusion of glucose, ribose, and other sugars into the portal veins of dogs. J. Lab. clin. Med. 69, 537-557 (1967).

9. Grodsky, G.M., A.A. BATTS, L.L. BENNETT, C. Voella, N.B. MoWilliams, and D.F. Sirrte: Effects of carbohydrates on secretion of insulin from isolated rat pancreas. Amer. J. Physiol. 205, 638-644 (1963).

10. HvG, G., and W.K. SchuBerT: Serum insulin type I glycogenosis. Effect of galactose or fructose administration. Diabetes 16, $791-795$ (1967).

11. IsselBaCHer, K.J. : Galactosemia. In: The Metabolic Basis of Inherited Disease, Stanbury, J.B., J.B Wyngaarden, and D.S. Fredperiokson, eds., p. 178. New York: McGraw-Hill 1966.

12. Lambert, A.E., B. Jeanrenaud, and A.E. Renold: personal communication.

13. - - - Enhancement by caffeine of glucagon-induced and tolbutamide-induced insulin release from isolated foetal pancreatic tissue. Lancet 1967 I, 819-820.

14. Matatsse, W., F. Malatsse-Lagat, and P.H. WRTGHT: A new method for the measurement in vitro of pancreatic insulin secretion. Endocrinology 80, $99-108$ (1967).

15. Pozza, G., G. Gatannsino, H. Hoffeld, and P.P. Fò̀ : Stimulation of insulin output by monosaccharides and monosaccharide derivatives. Amer. J. Physiol. 192, $497-500$ (1958).

16. Roth, H., S. SEGAL, and D. Bertoli : The quantitative determination of galactose. An enzymic method using galactose oxidase, with applications to blood and other biological fluids. Anal. Biochem. 10, 32-52 (1965).

17. SaMols, E., and T.T. DoRmandy: Insulin response to fructose and galactose. Lancet $1963 \mathrm{I}, 478-479$.

18. Sussman, K.E., G.D. Vaugran, and R.F. Timmer: An in vitro method for studying insulin secretion in the perfused isolated rat pancreas. Metabolism 15, $466-476(1966)$.

19. YALOW, R.S., and S.A. Berson: Immunoassay of plasma insulin. Meth. biochem. Anal. 12, 69-96 (1964).

Dr. R. GTTZELMand

Laboratory for Metabolic Research

University Pediatric Department

Kinderspital

CH-8032 Zürich, Switzerland 